\title{
Comparison of free fatty acid composition between low-fat and full-fat goat milk cheeses stored for 3 months under refrigeration
}

\author{
Wassim Nouira ${ }^{1}$, Young W. Park ${ }^{1 *}$, Zehra Guler ${ }^{2}$, Thomas Terrill ${ }^{1}$ \\ ${ }^{1}$ Georgia Small Ruminant Research \& Extension Center, Fort Valley State University, Fort Valley, USA; \\ ${ }^{2}$ Department of Food Engineering, Mustafa Kemal University, Antakya, Turkey; parky@,fvsu.edu
}

Received 17 May 2011, revised 12 June 2011, accepted 20 June 2011.

\begin{abstract}
Differences in free fatty acid (FFA) compositions between low-fat (LF) and full-fat (FF: whole milk) goat cheeses were evaluated during 3 months at $4^{\circ} \mathrm{C}$ refrigeration. The two types of cheeses were manufactured using a bulk milk from the mixed herd of Saanen, Alpine, and Nubian goat breeds. LF cheeses were made using LF milk after cream separation. FFAs of all cheeses were extracted in diisoprophyl ether using polypropylene chromatography column, and FFA concentrations were quantified using a gas chromatograph equipped with a fused silica capillary column. Moisture, fat, protein contents (\%) and $\mathrm{pH}$ of fresh LF and FF cheeses were: 55.1, 52.3; $1.30,25.6 ; 35.7,22.5 ; 5.40,5.42$, respectively. The FFA contents ( $\mathrm{mg} / \mathrm{g}$ cheese) of fresh FF and LF cheeses prior to storage treatments for C4:0, C6:0, C8:0, C10:0, C12:0, C14:0, C16:0, C18:0, C18:1, and C18:2 were: $0.020,0.072 ; 0.070,0.035$; $0.061,0.055 ; 0.181,0.167 ; 0.073,0.047 ; 0.174$, $0.112 ; 0.579,0.152 ; 0.308,0.202 ; 0.521,0.174$; and $0.057,0.026$, respectively. The respective FFA to total fatty acid ratios for 0,1 and 3 months aged FF and LF cheeses were 8.44, 12.4; $6.31,16.91 ; 12.03,14.19$. The LF cheeses generated more FFA than FF cheeses, while actual FFA content in FF cheese was significantly higher than in LF cheese. The FFA contents of LF cheese at 0, 1 and 3 months storage were $48.0,96.8$ and $36.4 \%$ of those of FF cheese, respectively. It was concluded LF cheese generated higher amount of FFA than FF cheese, although total FFA content was significantly $(P<0.05)$ lower in LF cheese than in FF cheese.
\end{abstract}

Keywords: Low Fat; Full Fat; Goat Milk Cheese;
Storage, Free Fatty Acid, Lipolysis

\section{INTRODUCTION}

Dietary fat has been implicated with coronary heart diseases, atherosclerosis, diabetes and other health problems. Consumption of reduced or low fat dairy products has been increasingly popular among health-conscientious consumers in recent years [1].

Fat reduction, however, presents a challenging problem because fat is important for texture and flavor of dairy products such as cheeses [2,3]. Fat reduction in hard and semi-hard cheeses results in undesirable rubbery texture, lack of flavor, and/or presence of off-flavors [3,4]. Reduced-fat (RF) and low-fat (LF) cheeses which possess the characteristics of traditional full-fat (FF) cheeses have been in demand [5]. Many manufacturing procedures, therefore, have been suggested and investigated to maximize sensory quality of RF cheeses [6-8].

A myriad of biochemical and physical changes can occur in goat milk cheeses after manufacture due to ripening and degradation of nutrients in the products [9-11]. Positive correlations have been found between lipolyzed flavor, fat acidity and short chain free fatty acid contents $[6,8,12]$. The flavor intensity of Kasar cheese, a hard cheese, was closely related to $\mathrm{C} 4$ - C10 free fatty acids [13]. The presence of large amounts of free fatty acids (FFA) can facilitate the rate of lipid oxidation, and free fatty acids oxidize slightly greater rate than esterified to glycerol. Even-numbered fatty acids from butyric to lauric accounted for the major contribution to rancid flavor $[11,14]$. Flavor deterioration from lipid oxidation (reaction of milk lipids with oxygen) and/or lipolysis in dairy products creates serious problems in storage stability of the products $[8,11,15,16]$.

The amount of FFA accumulated during ripening may be an overall measure of lipolysis, and is quite variable 
depending on the type of cheese, lactic and secondary starters, rennet type used, ripening time, and manufacturing methods and other factors [10,12,17]. The indigenous milk lipase, rennet preparation and microbes entered intentionally or unintentionally during cheese processing and ripening are primarily responsible for the extent of lipolysis $[12,17]$.

Although the effect of storage on levels of free fatty acids in low-fat and reduced-fat dairy cow products have been studied extensively, there is little information on such dairy goat products with respect to effect of storage, free fatty acid concentration and extent of lipolysis. Therefore, the objectives of this study were to: 1) determine free fatty acid (FFA) concentrations of low-fat (LF) and full-fat (FF) goat milk cheeses stored for three months under refrigeration, and 2) compare FFA contents between the two types of goat milk cheeses as well as between different storage periods in relation to lipolysis of the products.

\section{MATERIALS AND METHODS}

\subsection{Preparation of Goat Milk}

Goat milk used in this study was the bulk tank milk collected from the milking goat herd consisted of Saanen, Alpine and Nubian breeds at the Georgia Small Ruminant Research and Extension Center, Fort Valley State University, Fort valley, GA, USA. All goats were machine milked, and the experimental milks were pasteurized at $63^{\circ} \mathrm{C}\left(145^{\circ} \mathrm{F}\right)$ for 30 minutes before manufacture of the FF and LF experimental goat milk cheeses.

\subsection{Manufacture of Low-Fat (LF) and Full-Fat (FF) Goat Milk Cheeses}

Three batches of LF and 3 batches of FF semi-soft Cheddar-type caprine cheeses were manufactured at the University dairy plant, according to the modified procedures of Kosikowski [18] and Le Jaouen [19]. After pasteurization, the whole (FF) milk was cooled to $32^{\circ} \mathrm{C}$ in a $227 \mathrm{~L}$ cheese vat. Lyophilized mesophilic direct vat set starter culture (R704, 50 units, Chr. Hansen, Inc., Milwaukee, WI $)$ and single strength rennet $(10.6 \mathrm{~mL}$ of rennet per 100 L milk; Chymax; Chr. Hansen, Inc., Milwaukee, WI) were added to the milk and then allowed to coagulate for 30 minutes. The curd was cut using $1.6 \mathrm{~cm}$ wire knives and allowed to heal for 10 minutes. The temperature was gradually raised to $39^{\circ} \mathrm{C}$ over $30 \mathrm{~min}$ utes and the curd was cooked for 45 minutes, assuring for a firm curd. After draining whey, curds were salted at a rate of $2.5 \%$ of original milk weight and placed into $150 \times 150 \mathrm{~mm}$ cylindrical plastic molds and pressed at $40 \mathrm{psi}$ overnight at room temperature in a vertical cheese press (Pneumatic Press, Kusel Equip. Co., Watertown, WI). Cheeses were removed from the molds and vacuum packed in plastic pouches (FreshPak 500 vacuum pouches, Koch Supply, Kansas City, MO) using a vacuum packager (Koch Ultravac 250, Koch Supply, Kansas City, MO).

For LF cheese manufacture, cream was separated from the pasteurized whole goat milk by a cream separator (Model 17584, Clair Co., Althofen, Austria), and then the LF cheese was made from the low-fat milk according to the same procedure used for FF cheese.

\subsection{Experimental Design}

The experiment was conducted in a $2 \times 3 \times 3$ factorial arrangement. Two types (LF and FF) of goat milk cheeses were manufactured in three batches, and the experimental caprine cheeses were stored for 3 different storage (aging) periods ( 0,1 and 3 months).

All treated cheese samples were analyzed for basic chemical compositions, $\mathrm{pH}$, acid degree value (ADV) and free fatty acid and total fatty acid concentrations to determine the differences in the parameters between the two types of caprine milk cheeses.

\subsection{Chemical Analysis}

\subsubsection{Analyses of Basic Nutrient Composition}

Percents of fat, protein, ash and total solids contents were analyzed according to the procedures of A. O. A. C. [20] and Richardson [21].

\subsection{2. $\mathrm{pH}$ Analysis}

A $10 \mathrm{~g}$ cheese sample and $20 \mathrm{ml}$ deionized water were homogenized in a Waring blender (Waring Products, Inc., New Hartford, CT). The pH of the cheeses were determined using an Accumet model pH meter (No. 910; Fisher Scientific, Pittsburgh, PA).

\subsubsection{Acid Degree Value (ADV)}

The ADV refers to measure of the amount of free fatty acids present in a fat sample, which is a quantitative index of hydrolytic lipolysis in dairy products. ADV was determined by the Standard Methods for the Examination of Dairy Products [21]. Approximately $10 \mathrm{~g}$ of sample were grated, homogenized, and placed into a Babcock cheese bottle for fat extraction; $1 \mathrm{ml}$ of the final extracted fat was titrated against the standard alcoholic $0.02 \mathrm{~N} \mathrm{KOH}$ solution. Calculation of ADV was performed using the following formula:

$\mathrm{ADV}=\frac{\mathrm{ml} \mathrm{KOH} \text { for sample }-\mathrm{ml} \mathrm{KOH} \text { for blank } \times \mathrm{N} \times 100}{\text { Weight of fat }(g)}$

where $\mathrm{N}=$ normality of $\mathrm{KOH}$ solution in methanol. 


\subsubsection{Extraction of Free Fatty Acids in Cheese Samples}

Extraction of free fatty acids (FFA) was performed using the modified procedures of Deeth et al. [22]. A 1.5 $\mathrm{g}$ cheese sample was shredded and placed in a screw-capped test tube, and the internal standard $(5 \mathrm{~mL})$ $\mathrm{C} 5$ and $\mathrm{C} 17$ in diethyl ether, $0.3 \mathrm{~mL} 4 \mathrm{~N} \mathrm{H}_{2} \mathrm{SO}_{4}, 2.5 \mathrm{~g}$ $\mathrm{Na}_{2} \mathrm{SO}_{4}$, and hexane $(5 \mathrm{~mL})$ were added to the tube. The tube mixture was shaken for 1 min using a vortex mixer. Samples were allowed to stand for two hours. Then lipid extract was applied to a polypropylene column (Biorad, Los Angeles, CA, USA), which was conditioned with 5 $\mathrm{mL}$ hexane/diethyl ether $(1: 1, \mathrm{v} / \mathrm{v})$ and the extract passed through the column a second time. This was followed by $2 \times 5 \mathrm{~mL}$ hexane/diethyl ether $(1: 1, \mathrm{v} / \mathrm{v})$ to remove all triacylglycerols. FFAs were eluted with $2 \mathrm{~mL}$ diisopropyl ether containing 6\% formic acid (Merck, Darmstadt, Germany) and centrifuged at $2000 \times \mathrm{g}$ for $5 \mathrm{~min}$. A $2 \mathrm{~mL}$ aliquot of the supernatant was used for gas chromatographic analysis. For each sample, two extractions of FFAs were carried out, and two chromatographic injections made for each extract.

\subsubsection{Quantification of Free Fatty Acids in Cheeses}

FFA concentrations of cheese samples were quantified using a gas chromatograph (17A-GC, Shimadzu Co., Japan) equipped with a fused silica capillary column (DB-FFAP; $30 \mathrm{~m} \times 0.25 \mathrm{~mm}$ i.d. $\times 0.25 \mu \mathrm{m}$, Agilent Technologies, Wilmington, DE). Injector and detector temperature were 250 and $280^{\circ} \mathrm{C}$, respectively. Oven temperature was programmed from $50^{\circ} \mathrm{C}$ to $230^{\circ} \mathrm{C}$ at a rate of $5^{\circ} \mathrm{C}$ per minute, with initial and final hold times of 5 and $20 \mathrm{~min}$, respectively, and run time was $61 \mathrm{~min}$ utes. The injection mode was splittless for $1 \mathrm{~min}$, and the injection volume was $2 \mu \mathrm{L}$, with helium as carrier gas for $1 \mathrm{~mL} / \mathrm{min}$. Analyses were carried out in triplicate.

\subsubsection{Extraction and Quantification of Total Fatty Acids (TFA) in Cheeses}

The extraction and quantification of all fatty acids were performed using fatty acids methyl esters (FAME) according to A. O. C. S. procedure [23] with some modifications.

Total fatty acid compositions were determined by using a gas chromatograph (17A-GC, Shimadzu Co., Japan) equipped with a fused silica capillary column $(60 \mathrm{~m}$ length $\times 0.25 \mathrm{~mm}$ i.d. $\times 0.2 \mu \mathrm{m}$; SP 2380 , Supelco Inc., Bellfonate, PA) with a flame ionization detector (FID). Oven temperature was programmed from $50^{\circ} \mathrm{C}$ to $250^{\circ} \mathrm{C}$ at a rate of $4^{\circ} \mathrm{C} / \mathrm{min}$, with initial and final hold times of 2 and $10 \mathrm{~min}$. Injector and detector temperatures were 220 and $250^{\circ} \mathrm{C}$, respectively. The injection mode was split injection, and injection volume was one $\mu \mathrm{L}$. The carrier gas was helium at a rate of $2 \mathrm{~mL} / \mathrm{min}$.

\subsection{Statistical Analysis}

The experimental data were analyzed for analysis of variance, correlation coefficients and Duncan's multiple mean comparison as described by Steel and Torrie [24]. All data for unbalanced data were also analyzed by the general liner models procedure of SAS program [25].

\section{RESULTS AND DISCUSSION}

Basic nutrient compositions of experimental LF and FF goat milk and their respective cheeses are shown in Table 1. The respective fat contents (\%) of LF and FF goat milk were 0.41 and 3.66, while those of LF and FF cheeses were 1.30 and 25.6, indicating substantial differences $(P<0.01)$ in fat contents in LF and FF milk and cheeses. The protein contents of LF and FF milk were slightly different, whereas those of LF and FF cheeses were significantly $(P<0.01)$ different because fat was removed in the LF cheese which had more dense protein matrix than FF cheese.

When the acid degree values (ADV) were tested for the experimental cheeses, LF cheese regardless of the storage treatment did not have any detectable levels of ADV due to the original very low contents of fat in the cheeses (Table 2). However, the FF goat cheese showed continuous increase in ADV as the storage period advanced from 0 month to 3 months, indicating that no detectable lipolysis occurred in LF cheese while gradual increase in lipolysis occurred in FF cheese (Table 2). However, there were no differences in $\mathrm{pH}$ values between the FF and LF cheeses, nor between 0,1 and 3 moths storage periods as shown in (Table 2). In a previous report, $\mathrm{pH}$ of hard type goat cheeses were increased as the aging time advanced up to 6 months due to the formation of NH3 by catabolism of cheese proteins [16].

The FFA profiles of both FF and LF cheeses are shown in Table 3. Among all the detected free fatty acids, only C6:0, C10:0 and C12:0 showed significant $(P<$ $0.05)$ differences between the two cheeses during the 3 months storage period. The FF cheese contained the highest concentration of all these three free fatty acids after 3 months storage, indicating that FF cheese showed greater lipolysis evidenced by higher FFA level (Tables 2 and 3). All other free fatty acids except these 3 fatty acids did not show any statistically significant differences between treatments, even if a few values appeared to be a little high but not different due to the higher variations in concentration between samples. It was also observed that the relative abundance of FFA after 3 months refrigerated aging of FF goat cheese in the descending order of our cheese samples were: C18:0, 
Table 1. Basic composition (\%) of LF and FF goat milk and their respective cheeses.

\begin{tabular}{|c|c|c|c|c|c|c|c|c|}
\hline & \multicolumn{2}{|c|}{ Total solids } & \multicolumn{2}{|c|}{ Fat } & \multicolumn{2}{|c|}{ Protein } & \multicolumn{2}{|c|}{ Ash } \\
\hline & $\mathrm{X}$ & SD & $\mathrm{X}$ & SD & $\mathrm{X}$ & SD & $\mathrm{X}$ & SD \\
\hline \multicolumn{9}{|l|}{ Milk } \\
\hline LF & $9.72^{\mathrm{b}}$ & 0.92 & $0.41^{\mathrm{b}}$ & 0.07 & $3.32^{\mathrm{a}}$ & 0.09 & $0.53^{\mathrm{b}}$ & 0.09 \\
\hline $\mathrm{FF}$ & $11.72^{\mathrm{a}}$ & 1.52 & $3.66^{\mathrm{a}}$ & 0.08 & $3.22^{\mathrm{a}}$ & 0.11 & $0.69^{\mathrm{a}}$ & 0.01 \\
\hline \multicolumn{9}{|c|}{ Cheese } \\
\hline LF & $44.9^{\mathrm{a}}$ & 2.87 & $1.30^{\mathrm{b}}$ & 0.58 & $35.7^{\mathrm{a}}$ & 2.33 & $5.21^{\mathrm{a}}$ & 0.93 \\
\hline $\mathrm{FF}$ & $47.7^{\mathrm{a}}$ & 1.46 & $25.6^{\mathrm{a}}$ & 0.48 & $22.5^{\mathrm{b}}$ & 1.34 & $3.70^{\mathrm{b}}$ & 0.29 \\
\hline
\end{tabular}

$\mathrm{X}$ is mean, and SD is standard deviation values. ${ }^{\mathrm{a}, \mathrm{b}}$ Means with different superscripts within same columns are significantly different $P<0.01$ or 0.05 ). The differences for fat and protein contents between FF and LF milk and cheese groups are significant at $P<0.01$. The mean comparisons are made separately for milk samples and for cheese samples within the same columns.

Table 2. Summary of mean $\mathrm{pH}$ and ADV of FF and LF goat milk cheeses during 3 months refrigerated storage.

\begin{tabular}{|c|c|c|c|c|c|c|c|c|c|c|c|c|}
\hline & \multicolumn{4}{|c|}{0 month } & \multicolumn{4}{|c|}{1 month } & \multicolumn{4}{|c|}{3 month } \\
\hline & \multicolumn{2}{|c|}{ FF } & \multicolumn{2}{|c|}{ LF } & \multicolumn{2}{|c|}{ FF } & \multicolumn{2}{|c|}{ LF } & \multicolumn{2}{|c|}{ FF } & \multicolumn{2}{|c|}{ LF } \\
\hline & $\mathrm{X}$ & SD & $\mathrm{X}$ & SD & $\mathrm{X}$ & SD & $\mathrm{X}$ & SD & $\mathrm{X}$ & SD & $\mathrm{X}$ & SD \\
\hline $\mathrm{pH}$ & $5.40^{\mathrm{a}}$ & 0.01 & $5.42^{\mathrm{a}}$ & 0.01 & $5.43^{\mathrm{a}}$ & 0.01 & $5.43^{\mathrm{a}}$ & 0.02 & $5.28^{\mathrm{a}}$ & 0.0 & $5.48^{\mathrm{a}}$ & 0.02 \\
\hline ADV & $0.70^{\mathrm{a}}$ & 0.08 & 0.0 & - & $1.06^{\mathrm{b}}$ & 0.05 & 0.0 & - & $1.34^{\mathrm{bc}}$ & 0.07 & 0.0 & - \\
\hline
\end{tabular}

$\mathrm{X}$ is mean; $\mathrm{SD}$ is standard deviation; a,b,c Means with different superscript within same row is different $(P<0.05)$

Table 3. Comparison of mean free fatty acid concentration ( $\mathrm{mg} / \mathrm{g}$ cheese) of full-fat (FF) with low-fat (LF) goat milk cheeses aged for 3 months under refrigeration.

\begin{tabular}{ccccccc}
\hline & \multicolumn{2}{c}{ 0 month } & \multicolumn{2}{c}{ 1 month } & \multicolumn{2}{c}{ 3 month } \\
\cline { 2 - 7 } FFA & FF & LF & FF & LF & FF & LF \\
\hline C4:0 & $0.0202^{\mathrm{a}}$ & $0.072^{\mathrm{a}}$ & $0.0104^{\mathrm{a}}$ & $0.0325^{\mathrm{a}}$ & $0.0524^{\mathrm{a}}$ & $0.034^{\mathrm{a}}$ \\
C6:0 & $0.0701^{\mathrm{ab}}$ & $0.0353^{\mathrm{b}}$ & $0.0497^{\mathrm{ab}}$ & $0.0565^{\mathrm{ab}}$ & $0.2153^{\mathrm{a}}$ & $0.0925^{\mathrm{ab}}$ \\
C8:0 & $0.0609^{\mathrm{a}}$ & $0.0551^{\mathrm{a}}$ & $0.0575^{\mathrm{a}}$ & $0.0411^{\mathrm{a}}$ & $0.1222^{\mathrm{a}}$ & $0.0638^{\mathrm{a}}$ \\
C10:0 & $0.1805^{\mathrm{b}}$ & $0.1066^{\mathrm{b}}$ & $0.1620^{\mathrm{b}}$ & $0.1007^{\mathrm{b}}$ & $0.4706^{\mathrm{a}}$ & $0.1253^{\mathrm{b}}$ \\
C12:0 & $0.0729^{\mathrm{b}}$ & $0.0474^{\mathrm{b}}$ & $0.0649^{\mathrm{b}}$ & $0.0558^{\mathrm{b}}$ & $0.2511^{\mathrm{a}}$ & $0.0501^{\mathrm{b}}$ \\
C14:0 & $0.1744^{\mathrm{a}}$ & $0.1119^{\mathrm{a}}$ & $0.1575^{\mathrm{a}}$ & $0.1173^{\mathrm{a}}$ & $0.2231^{\mathrm{a}}$ & $0.1492^{\mathrm{a}}$ \\
C16:0 & $0.5794^{\mathrm{a}}$ & $0.1520^{\mathrm{a}}$ & $0.3839^{\mathrm{a}}$ & $0.1451^{\mathrm{a}}$ & $0.5113^{\mathrm{a}}$ & $0.2401^{\mathrm{a}}$ \\
C18:0 & $0.3076^{\mathrm{a}}$ & $0.2022^{\mathrm{a}}$ & $0.1892^{\mathrm{a}}$ & $0.1540^{\mathrm{a}}$ & $0.7423^{\mathrm{a}}$ & $0.1111^{\mathrm{a}}$ \\
C18:1 & $0.5211^{\mathrm{a}}$ & $0.1740^{\mathrm{a}}$ & $0.3332^{\mathrm{a}}$ & $0.6455^{\mathrm{a}}$ & $0.4816^{\mathrm{a}}$ & $0.2332^{\mathrm{a}}$ \\
C18:2 & $0.0572^{\mathrm{a}}$ & $0.0255^{\mathrm{a}}$ & $0.0875^{\mathrm{a}}$ & $0.1000^{\mathrm{a}}$ & $0.2744^{\mathrm{a}}$ & $0.1175^{\mathrm{a}}$ \\
Total FFA & $2.0443^{\mathrm{b}}$ & $0.982^{\mathrm{d}}$ & $1.4957^{\mathrm{bc}}$ & $1.4485^{\mathrm{bc}}$ & $3.3443^{\mathrm{a}}$ & $1.2168^{\mathrm{c}}$ \\
Total fatty acids & $24.226^{\mathrm{ab}}$ & $7.917^{\mathrm{a}}$ & $23.719^{\mathrm{ab}}$ & $8.568^{\mathrm{c}}$ & $27.798^{\mathrm{a}}$ & $8.574^{\mathrm{c}}$ \\
FFA/TFA ratio & 8.44 & 12.4 & 6.31 & 16.9 & 12.03 & 14.2 \\
\hline
\end{tabular}

$\mathrm{a}, \overline{\mathrm{b}, \mathrm{c}, \mathrm{d}}$ Means with different superscripts in same row are different $(P<0.05$ or $P<0.01)$. All FFA values are means of 3 batches of cheeses, and each batch samples were analyzed in duplicates.

C16:0, C18:1, C10:0, C12:0. C14:0, and C6:0 acid. Attaie and Richter [26] reported that aging time greatly influenced levels of volatile FFA in goat Cheddar cheese for the first 3 months, then remained relatively un- 
changed for the rest of the 6 months aging period. They also observed the descending order of the relative abundance of FFA in their goat Cheddar cheese were: C10:0, C12:0, C8:0, C6:0 and C4:0 acid, which may not be directly comparable to our results, since they determined the concentrations of volatile fatty acids (C4:0 to C12:0).

With respect to total FFA and total fatty acid (TFA) concentrations, the respective levels of the FF goat milk cheese for the 0,1 and 3 months aging were: 2.04, 24.2; $1.50,23.7 ; 3.34,27.8$, whereas the LF cheese of the corresponding aging periods were $0.982,7.917 ; 1.449$, $8.568 ; 1.217,8.574$, respectively. These results also clearly show that the LF cheese contained considerably lower levels of FFA and TFA, compared to the FF cheese (Table 3). Total FFA concentrations of FF and LF goat cheeses after 3 months refrigerated storage increased from 2.044 to 3.344 , and 0.982 to $1.217 \mathrm{mg} / \mathrm{g}$ cheese, respectively. These results indicate that some increase $(1.30 \mathrm{mg} / \mathrm{g}$ cheese) in lipolysis occurred in FF goat milk cheese, but very minimal change $(0.235 \mathrm{mg} / \mathrm{g}$ cheese $)$ occurred in LF goat cheese during the 3 months experimental storage period. These FFA concentrations are reflected with the results of ADV values shown in Table 2. Positive correlations were found between lipolyzed flavor, fat acidity, and short-chain FFA contents $[6,11,17]$ Even-numbered fatty acids, from butyric to lauric acid, in milk and dairy products account for the major contribution to rancid flavor $[11,14]$.

In light of total FFA to total fatty acids (TFA) ratios of both FF and LF cheeses, LF cheese showed relatively higher ratio than that of FF cheese. However, the actual increase in FFA content of LF cheese was much smaller than that of FF cheese, simply because LF cheese contained substantially lower fat content than FF cheese (Tables 1 and 3; Figure 1). Figure 1 demonstrates that total fatty acid concentrations of FF cheeses were substantially higher than those of LF cheeses, regardless of storage times. The figure also shows that the differences in concentration (mg/g cheese) between FFA and TFA are much greater in FF cheese than LF cheese throughout the storage periods. The relatively greater FFA/TFA ratio in LF cheese compared to that in FF cheese can be attributed to the disrupted fat globule membranes of LF cheese which can have a greater chance of exposure to lipolytic enzymes by cream separation as well as cheese processing and storage. The origin of enzymes responsible for lipolysis in cheese include the indigenous milk lipase (lipoprotein lipase: LPL), rennet preparation, and microbes that develop during cheese ripening either intentionally (starter bacteria and specific molds or yeasts) or unintentionally (nonstarter acid bacteria and adventitious molds or yeasts) that should not be present at significant numbers $[12,17,27]$. The LPL activity, although

Copyright $\odot 2011$ SciRes. lower in goat than in cow milk, is more bound to the fat globules and better correlated to spontaneous lipolysis in goat milk [28]. On the other hand, the undisrupted fats without cream separation in FF cheese would have less exposure to the lipase enzymes, resulting in less chance of lipolysis in the FF cheese. Although the milk was pasteurized before cream separation, there would be chances of the intentional and unintentional microbial lipases activities during processing and storage of our experimental goat cheeses.

Reports also have shown that lipolysis of milk and dairy products can occur by three different sources: 1 ) induced lipolysis, 2) spontaneous lipolysis and 3) microbial lipolysis $[11,29]$. Induced lipolysis is influenced by several factors, such as processing factors including agitation, separation, pumping, mixing, foaming, presence of air, homogenization, activation by temperature changes, freezing and thawing, storage and processing $[11,29,30]$. Spontaneous lipolysis can occur through two main factors, such as milk processing factors, and milking animal factors including stage of lactation, feed, season, breed, mastitis, milk and fat yield, and physiological factors. Microbial lipolysis is caused by many microorganisms that contaminate dairy products. These organisms produce lipase which develop rancid flavor. The psychrotrophic bacteria are most common sources of these lipases [11]. Bacterial lipases are different from milk lipases, are not inactivated by pasteurization, and can attack the intact fat globules in milk $[12,27,30]$. Since LF cheese manufacture after cream separation in this study could be prone to be involved in these three types of lipolysis, higher lipid hydrolysis might have been occurred in the LF cheeses, causing a higher proportional increase of FFAs in LF cheeses even though the FFA amount was small.

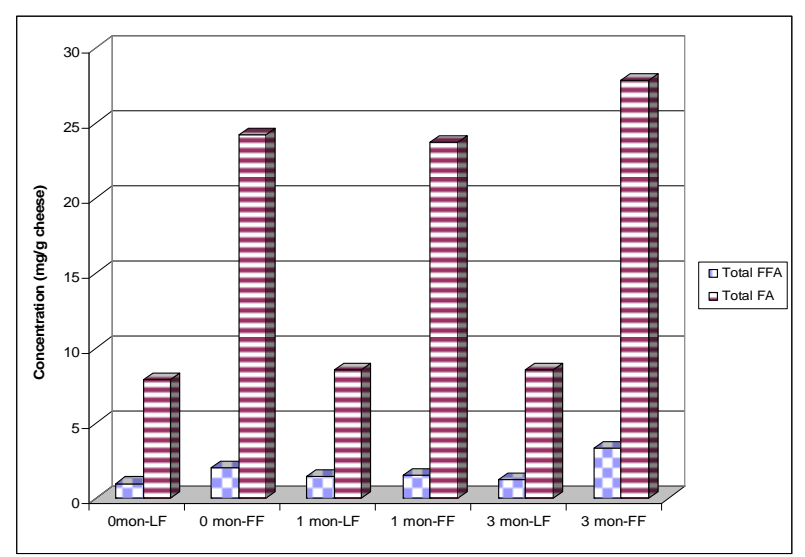

Figure 1. Comparison of levels ( $\mathrm{mg} / \mathrm{g}$ cheese) of total free fatty acids (FFA) and total fatty acids (TFA) between LF and FF goat milk cheeses for 3 months refrigerated storage [Differences between LF and FF cheeses were significant $(P<$ $0.01)]$. 


\section{CONCLUSIONS}

The profiles of free fatty acid compositions of the 0 to 3 months aged FF and LF caprine cheeses revealed that FF cheeses contained higher levels of all types of free fatty acids, except for the butyric acid in the initial cheeses. The total FFA contents of LF cheese were 48.0, 96.8 and $36.4 \%$ of FF cheeses for 0,1 and 3 months aging, indicating that the 1 month aged cheeses contained higher FFA than the 0 and 3 month stored ones. The LF cheese revealed more proportional increase in FFA compared to the FF cheese, although the actual amount of FFA in LF cheese was much lower than that in FF cheese. This result may account for the higher lipolytic enzyme activities in LF cheese by the indigenous milk enzymes, or microbial enzymes of intentional and unintentional microorganisms which can have a greater access to the disrupted fat globule membranes by cream separation and subsequent cheese processing and storage. Further studies may be necessary to ascertain what exact sources or mechanisms are involved in the elevation of FFA in LF caprine cheeses in order to prevent the increased lipolysis which may deteriorate the quality of low-fat goat milk cheeses.

\section{ACKNOWLEDGEMENTS}

This study was supported by USDA 1890 Capacity Building Grant, Award No. 2007-38814-18518. The authors greatly appreciate Mr. Schauston Miller and Carlton Green for collection of goat milk and processing, and Ms. Ruby Ragan for her assistance in cheese manufacture. Dr. Zehra Güler was supported by the Scientific and Technological Research Council of Turkey, with 2219-postdoctoral research fellowships (TÜBİTAK-TURKEY, 2008) for a visiting scientist at Fort Valley State University, Fort Valley, GA, USA.

\section{REFERENCES}

[1] Thayer, A.M. (1992) Food Additives. Chemical Engineering News, 70, 26. doi:10.1021/cen-v070n024.p026

[2] Jameson, G.W. (1990) Cheese with less fat. Australian Journal of Dairy Technology, 11, 93.

[3] Mistry, V.V. (2001) Low fat cheese technology. International Dairy Journal, 11, 413-422. doi:10.1016/S0958-6946(01)00077-2

[4] Olson, N.F. and Johnson, M.E. (1990) Light cheese products: characteristics and economics. Food Technology, 44, 93-96.

[5] Honer, C. (January 1993). Second thoughts. Dairy Field. Skokie.

[6] Drake, M.A., Herrett, W., Boylston, T.D. and Swanson, B.G. (1995) Sensory evaluation of reduced fat cheeses. Journal of Food Science, 60, 898-901. doi:10.1111/j.1365-2621.1995.tb06256.x

[7] Ashfield, M.A., Ma, L., Drake, M.A., Barbosa-Canovas, G.V. and Swanson, B.G. (1997) Rheology of full-fat and low-fat Cheddar cheeses as related to type of fat mimetic.

Copyright $\odot 2011$ SciRes.
[8] Carunchia Whetstine, M.E., Karagul-Yuceer, Y., Avsar, Y. and Drake, M.A. (2003) Identification and quantification of character aroma components in fresh Chevre-style goat cheese. Journal of Food Science, 68, 2441-2447. doi:10.1111/j.1365-2621.2003.tb07043.x

[9] Fox, P.F. (1989) Proteolysis during cheese manufacture and ripening. Journal of Dairy Science, 72, 1379-1400. doi:10.3168/jds.S0022-0302(89)79246-8

[10] McSweeney, P. and Sousa, M. (2000). Biochemical pathways for the production of flavor compounds in cheese during ripening: A review. Lait, 80, 293-324. doi:10.1051/lait:2000127

[11] Park, Y.W. (2001) Proteolysis and lipolysis of goat milk cheese. Journal of Dairy Science, 84 (E. Suppl.), E84-E92.

[12] Velez, M.A., Perotti, M.C., Wolf, I.V., Hynes, E.R. and Zalazar, C.A. (2010) Influence of milk pretreatment on production of free fatty acids and volatile compounds in hard cheeses: Heat treatment and mechanical agitation. Journal of Dairy Science, 93, 4545-4554. doi:10.3168/jds.2010-3352

[13] Guler, Z. (2005) Quantification of free fatty acids and flavor characteristics of Kasar cheeses. Journal of Food Lipids, 12, 209-221. doi:10.1111/j.1745-4522.2005.00018.x

[14] Ha, J.K. and Lindsay, R.C. (1991) Contributions of cow, sheep, and goat milks to characterizing branched-chain fatty acid and phenolic flavors in varietal cheeses. Journal of Dairy Science, 74, 3267-3274. doi:10.3168/jds.S0022-0302(91)78512-3

[15] Day, E.A. (1960) Autoxidation of milk lipids. Journal of Dairy Science, 43, 1064. doi:10.3168/jds.S0022-0302(60)90329-5

[16] Jin, Y.K. and Park, Y.W. (1995) Effects of aging time and temperature on proteolysis of commercial goat cheeses in the US. Journal of Dairy Science, 78, 2598-2608. doi:10.3168/jds.S0022-0302(95)76888-6

[17] Collins, Y., McSweeney, P.L.H. and Wilkinson, M. (2003) Lipolysis and free fatty acid catabolism in cheese: A review of current knowledge. International Dairy Journal, 13, 841-846. doi:10.1016/S0958-6946(03)00109-2

[18] Kosikowski, F.V. (1977) Cheese and fermented milk foods, 2nd Edition, Edwards Brothers, Inc., Ann Arbor, 437-440.

[19] Le Jaouen, J.-C. (1987) The fabrication of farmstead goat cheese. Cheesemaker's Journal,Ashfield,MA 01330, 45.

[20] AOAC. (1985) Official methods of analysis. 14th Edition, The Association of Official Analytical Chemists, Washngton, D.C. No. 43.292. 7.001, 7.009, 7.006.

[21] Case, R.A., Bradley, R.L. Jr. and Williams, R.R. (1985) Chemical and physical methods. In: Richardson, G.H. Ed., Standard Methods for the Examination of Dairy Products.15th Edition, American Public Health Association, Washington, D.C., 327.

[22] Deeth, H.C., Fitz-Gerald, C.H. and Snow, A.J. (1983) A GC method for the quantitative assay of free fatty acids. New Zealand Journal of Science and Technology, 18, 13-20.

[23] AOCS. (1975) Official methods and recommended practices of the american oil chemists' society. American Oil Chemists' Society, Champaign, No. 1, 3A and 6, 7-15.

[24] Steel, R.G.D. and Torrie, J.H. (1960) Principles and Pro- 
cedures of statistics. McGraw-Hill, New York, 190.

[25] SAS Institute. (1999) User's guide: statistics, 8th Edition. SAS Institute, Inc., Cary.

[26] Attaie, R. and Richter, R.L. (1996) Formation of volatile free fatty acids during ripening of Cheddar-like hard goat cheese. Journal of Dairy Science, 79, 717-724. doi:10.3168/jds.S0022-0302(96)76418-4

[27] Hickey, D.K., Kilcawley, K.N., Beresford, T.P. and Wilkinson, M.G. (2007) Lipolysis in cheddar cheese made from raw, thermized, and pasteurized milks. Journal of Dairy Science, 90, 47-56. doi:10.3168/jds.S0022-0302(07)72607-3
[28] Chilliard, Y., Ferlay, A., Rouel, J. and Lamberet, G. (2003) A review of nutritional and physiological factors affecting goat milk lipid synthesis and lipolysis. Journal of Dairy Science, 86, 1751-1770. doi:10.3168/jds.S0022-0302(03)73761-8

[29] Deeth, H.C. and Fitz-Gerald, C.H. (1976) Lipolysis in dairy products: A review. Australian Journal of Dairy Technology, 31, 53-64. doi:10.1016/j.idairyj.2004.01.005

[30] Evers, J.M. (2004) The milkfat globule membrane-Compositional and structural changes post secretion by the mammary secretory cell. International Dairy Journal, 14, 661-674. 